2016 - Volume: 17 Number: 1

Page: $181-190$

DOI : $10.18038 /$ btda. 45168

Received: 15 February 2016

Revised: 10 March 2016

Accepted: 01 April 2016

\title{
IMPROVEMENT OF THE CRYSTALLINITY AND OPTICAL PARAMETERS OF ZnO FILM WITH ALUMINUM DOPING
}

\author{
Saliha ILICAN \\ Department of Physics, Science Faculty, Anadolu University, 26470, Eskişehir, Turkey
}

\begin{abstract}
In this study, the undoped and Aluminum $(\mathrm{Al})$ doped $(1 \%$ and $3 \%)$ zinc oxide $(\mathrm{ZnO})$ films were prepared by sol gel method via spin coating onto glass substrates. To investigate the structural and optical properties of the films, it was used to X-ray diffractometer and UV-VIS spectrophotometer, respectively. The prepared $\mathrm{ZnO}$ films are polycrystalline with a hexagonal wurtzite structure with a preferential orientation according to the (002) plane. The crystalline quality of $\mathrm{ZnO}$ film was improved by the increase of $\mathrm{Al}$ content. So, the most intense of (002) peak is observed for 3\% Al-doped $\mathrm{ZnO}$ film. According to UV-vis spectroscopy spectra, the average optical transmittance and reflectance of all the films are greater than $76 \%$ and $14 \%$ in the visible range, respectively. The different methods were used to evaluate the absorption edges of the prepared films depending on the $\mathrm{Al}$ dopants. The optical band gap value of $\mathrm{ZnO}$ film shifted towards to the blue region in the first incorporation of $\mathrm{Al}$ in $\mathrm{ZnO}$ film, and then, this value shifted towards the red region with increasing Al content. The optical constants such as refractive index, extinction coefficient and dielectric constants were determined for undoped and $\mathrm{Al}$ doped $\mathrm{ZnO}$ films. The refractive index dispersion of the films was analyzed by using the single oscillator model. The dispersion parameters such as oscillator energy and dispersion energy values of the prepared films were determined.
\end{abstract}

Keywords: Al doped $\mathrm{ZnO}$ films, Sol gel, Optical band gap, Optical constants, Dispersion parameters

\section{ZnO FILMININ KRISTALLİĞi VE OPTIK PARAMETRELERININN ALÜMINYUM KATKISI İLE IYYILEŞTİRILMESI}

\begin{abstract}
ÖZET
Bu çalışmada, katkısız ve alüminyum (Al) katkı1ı (\%1 ve \%3) çinko oksit (ZnO) filmleri cam alttaşlar üzerine spin kaplama tekniği ile sol jel metodu kullanılarak elde edilmiştir. Filmlerin yapısal ve optik özelliklerini incelemek için sırasıyla, X-1şınları difraktometresi ve UV-vis spektrofotometresi kullanılmıştır. Elde edilen filmler polikristal olup, hekzagonal wurtzite yapıda ve (002) tercihli yönelimine sahiptirler. ZnO filminin kristal kalitesi, artan Al katkısı ile artmıştır. Bu nedenle, en şiddetli (002) piki \%3 Al katkılı ZnO filminde gözlenmiştir. UV-vis spektrofotometresine göre, filmlerin görünür bölgedeki ortalama transmittans ve reflektansları, sırasıyla \%76 ve \%14 değerinden büyüktür. Elde edilen filmlerin Al katkısına bağlı olarak absorpsiyon kenarlarını belirlemek için farklı metotlar kullanılmıştır. ZnO filminin optik bant aralığı, ilk Al katkısı ile mavi bölgeye kaymış, ve daha sonra Al katkı miktarı arttırılınca, kırmızı bölgeye kaymıştır. Kırılma indisi, sönüm katsayısı ve dielektrik sabitleri gibi optik sabitler katkısız ve Al katkılı ZnO filmleri için belirlenmiş̧ir. Filmlerin kırılma indisi dispersiyonu, single oscillator model kullanılarak analiz edilmiştir. Elde edilen filmlerin osilatör enerjisi ve dispersiyon enerjisi gibi dispersiyon parametreleri belirlenmiştir.
\end{abstract}

Anahtar Kelimeler: Al katkılı ZnO filmleri, Sol jel, Optik bant aralığı, Optik sabitler, Dispersiyon parametreleri

\section{INTRODUCTION}

Wide optical band gap II-VI semiconductors, especially Zinc Oxide $(\mathrm{ZnO})$ was subject to most intensive research for several decades. Because, $\mathrm{ZnO}$ is a significant material as an optoelectronic device material owing to possess physical properties such as wide band gap $(\approx 3.3 \mathrm{eV}$ at $300 \mathrm{~K})$, large exciton binding energy $(60 \mathrm{meV})$, high optical transparency and electrical conductivity [1]. To further improve these properties of $\mathrm{ZnO}$, it can be doped with a group IIIA elements such as $\mathrm{Al}^{3+}, \mathrm{In}^{3+}, \mathrm{Ga}^{3+}[2-8]$.

\footnotetext{
*Corresponding Author: silican@anadolu.edu.tr
} 
To date, both physical and chemical processes have been used to deposit of $\mathrm{Al}$ doped $\mathrm{ZnO}$ films. The sol gel method is one of the chemical processes, and a versatile method due to some advantages with low cost and simple experimental set-up equipment, can be made easy doping and easy fabrication of large-area films. Therefore, many research groups have prepared $\mathrm{Al}$ doped $\mathrm{ZnO}$ films by sol gel method and characterized of them. Kim et al. [9] prepared $\mathrm{Al}$ doped $\mathrm{ZnO}$ films by spin coating technique. They reported that all the films were highly transparent and the optical band gap of the prepared Al doped $\mathrm{ZnO}$ films exhibited higher value than undoped $\mathrm{ZnO}$ film. It is the increase of band gap by the doping of Al, in agreement with Burstein-Moss effect. Khan et al. [10] reported the influence of Al on structural, morphological and optical properties $\mathrm{Al}$ doped $\mathrm{ZnO}$ films prepared by the spin coating technique. They observed an increase in the optical band gap with an increase in $\mathrm{Al}$ composition in $\mathrm{ZnO}$. They concluded their prepared $\mathrm{Al}$ doped $\mathrm{ZnO}$ films had potential applications in the fabrication of light emitting devices. Caglar et al. [5] studied the microstructural, optical and electrical properties of $\mathrm{Al}$ doped $\mathrm{ZnO}$ films deposited by a spin coating technique. In their study, it is emphasized that optical band gap, crystallite size and texture coefficient of $\mathrm{ZnO}$ film decreased whereas electrical conductivity increased with increasing $\mathrm{Al}$ content. Al-Ghamdi et al. [2] also prepared $\mathrm{ZnO}$ films with $\mathrm{Al}$ content by the same technique and reported that $\mathrm{Al}$ incorporation increased the optical band gap, electrical conductivity, mobility carriers and carrier concentration, but decreased the lattice parameters.

Above these studies had focused on the structural parameters, morphological properties, optical band gap and electrical conductivity of sol gel derived $\mathrm{Al}$ doped $\mathrm{ZnO}$ films, whereas there are only a few reports on its optical constants and dispersion parameters of that films [11-13]. Therefore, the main goal of this study is to investigate the correlation between the Al content and its effect on structural and optical properties of $\mathrm{ZnO}$ films were prepared by sol gel method, furthermore the effect of Al content on the optical constants and dispersion parameters of sol gel derived $\mathrm{ZnO}$ film.

\section{EXPERIMENTAL DETAILS}

Glass substrates were sonicated with ethanol and DI water, subsequently rinsed with acetone water, and dried $\mathrm{N}_{2}$ gas. The precursor solutions with a concentration of $0.5 \mathrm{M}$ were prepared by using zinc acetate dihydrate $\left[\mathrm{Zn}\left(\mathrm{CH}_{3} \mathrm{COO}\right)_{2} \cdot 2 \mathrm{H}_{2} \mathrm{O}, \mathrm{ZnAc}\right], 2$-methoxyethanol and monoethanolamine. The solution was stirred in clear solution at $40^{\circ} \mathrm{C}$ for $1 \mathrm{~h}$, and then was coated by spin coating (3000rpm, 30s) onto cleaned substrate. The wet film was preheated at $300^{\circ} \mathrm{C}$ after each coating. In order to obtain well-crystallized film, it was finally annealed at $550^{\circ} \mathrm{C}$ for $1 \mathrm{~h}$ in air after tenth coating. Finally, it was served cooling at room temperature. For $\mathrm{Al}$ doped $\mathrm{ZnO}$ films, Aluminum chloride was used as a dopant source with the same preparation procedure, and mixed to the precursor solution with a nominal volume ratio $1 \%$ and $3 \% \mathrm{Al}$. The deposition process was conducted for all prepared solutions to deposit films of different $\mathrm{Al}$ concentrations.

To check the crystalline phase and crystallite orientation of $\mathrm{Al}$ doped $\mathrm{ZnO}$ films was used by an X-ray diffractometer (BRUKER D2 Phaser) equipped with $C u K_{\alpha}$ radiation $(\lambda=1.5406 \mathrm{~nm})$. The optical reflectance and transmittance spectra of the prepared $\mathrm{ZnO}$ films were measured by SHIMADZU UV2450 spectrophotometer with an integrating sphere attachment. A bare glass substrate was used as the reference sample. The thicknesses of the undoped and $\mathrm{Al}$ doped $\mathrm{ZnO}$ films were determined by using weighing method with Mettler Toledo MX5 microbalance, and found to be approximately 400nm.

\section{RESULTS AND DISCUSSION}

\subsection{Crystallinity of the Prepared Undoped and Al Doped ZnO Films}

To investigate the crystallinity and preferred orientations of the prepared undoped and $\mathrm{Al}$ doped $\mathrm{ZnO}$ films, it was used to the XRD method. XRD spectra of these films are given in Fig. 1. All of the spectra are indexed to a $\mathrm{ZnO}$ hexagonal wurtzite structure (Zincite phase, JCPDS card file no: 36-1451). Only 
one peak, corresponding to the (002) phase, appeared on the XRD spectra. No other impurity phase related to aluminum is observed. So, these films are preferentially oriented along the c-axis direction. The intensity of the (002) peak increases, indicating that the crystalline quality of the $\mathrm{ZnO}$ film enhances with incorporation of $\mathrm{Al}$. In addition to, 2theta angles of (002) peaks for undoped, 1\% Al doped and $3 \% \mathrm{Al}$ doped $\mathrm{ZnO}$ films were observed at $34.385^{\circ}, 34.408^{\circ}$ and $34.431^{\circ}$, respectively. Mondal et al. [14] and Baba et al. [15] reported similar results. That is, $\mathrm{Al}$ incorporation causes the shift towards the big angle for the (002) peak direction. This presumably results from the substitution of $\mathrm{Zn}^{2+}$ by smaller ionic radii of $\mathrm{Al}^{3+}\left(r_{\mathrm{Al} 3+}=0.53 \AA<r_{\mathrm{Zn} 2+}=0.74 \AA\right)$. That is, this shift implies due to difference in ionic radius of and $\mathrm{Zn}^{2+}$ and $\mathrm{Al}^{3+}$. Therefore, the substitution of by $\mathrm{Al}^{3+}$ may have caused this decrease.

\subsection{Optical Band Gap of the Prepared Undoped and Al Doped ZnO films}

The transmittance and reflectance studies are important methods for optical properties of the films. To determine the optical band gap $\left(E_{g}\right)$ or corresponding absorption edge several well-known methods have been used. In this study, the absorption edges of the undoped and $\mathrm{Al}$ doped $\mathrm{ZnO}$ films were determined by using both transmittance (Fig. 2a) and diffuse reflectance (Fig. 2b) spectra and compared with each other. The first derivative of transmittance $(\mathrm{d} T / \mathrm{d} \lambda)$ was deduced to determine the absorption edges and plotted in Fig. 3a. The maxima in the first derivative curves refer to the band gap energies of the prepared films. As seen from this figure, the absorption edge shifts towards the ultraviolet region with $\mathrm{Al}$ incorporation. This shift is attributed to Moss-Burstein effect, caused by an increase in free electron concentration because of $\mathrm{Al}$ incorporation. It is observed the red shift when $\mathrm{Al}$ content is increased. This shift is associated with shrinkage effect due to increasing carrier concentration.

In another method the diffuse reflectance data are used for determination of the absorption edge. The differential reflectance $\mathrm{d} R / \mathrm{d} \lambda$ versus $\lambda$ is also given in Fig. $3 \mathrm{~b}$. The $E_{g}$ value for undoped and Al doped $\mathrm{ZnO}$ films determine using the maximum values of these plots. The values determined by this method also show the same trend.

In the third method, the direct optical band gap energies of the films can be determined according to the Tauc model, which is using a plot of $(\alpha h v)^{2}$ vs. the photon energy. The Tauc model could be expressed as [16],

$(\alpha h v)=B\left(h v-E_{g}\right)^{1 / 2}$

where $B$ is a constant and $\alpha$ is absorption coefficient which is given by

$\alpha=\frac{4 \pi k}{\lambda}$

The $E_{g}$ values were determined from Fig.4 and the same variation was observed again. The same trend in $E_{g}$ value with $\mathrm{Al}$ incorporation into $\mathrm{ZnO}$ was also observed by the others researchers $[15,17]$. The detail of the $E_{g}$ values determined from different methods is given in Fig. 5. The variation of the band gap energy with the $\mathrm{Al}$ content is more clearly shown from this figure. It can be seen that the results obtained from these methods are very close to each other. 
Ilıcan / Anadolu Univ. J. of Sci. and Technology-A - Appl. Sci. and Eng. 17 (1) - 2016

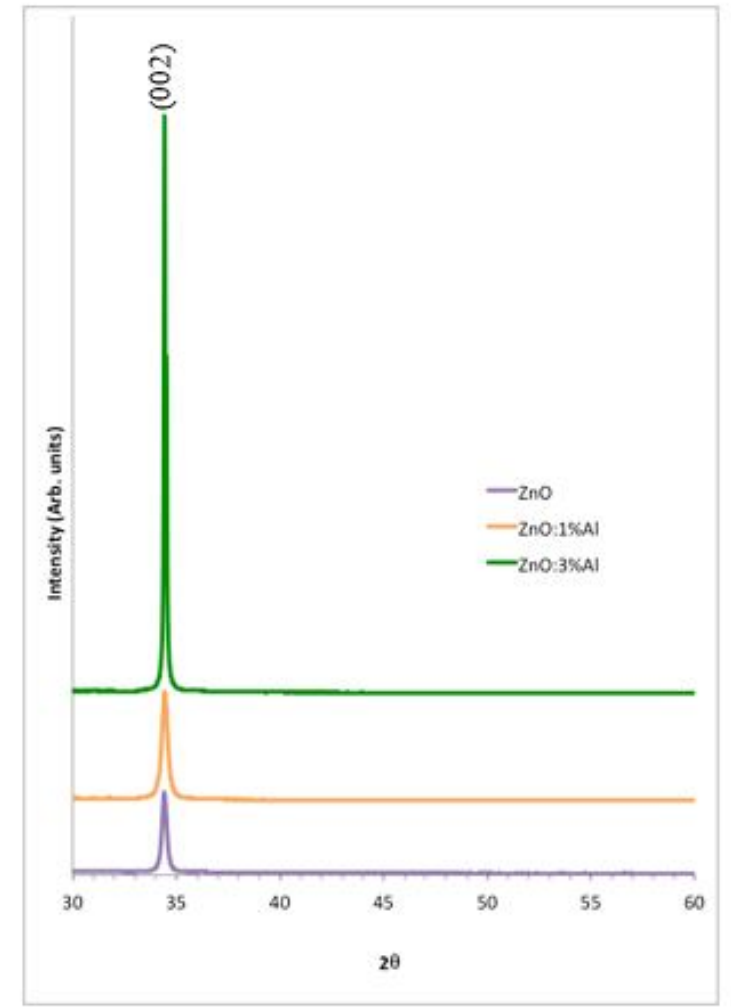

Figure 1. XRD spectra of the undoped and $\mathrm{Al}$ doped $\mathrm{ZnO}$ films
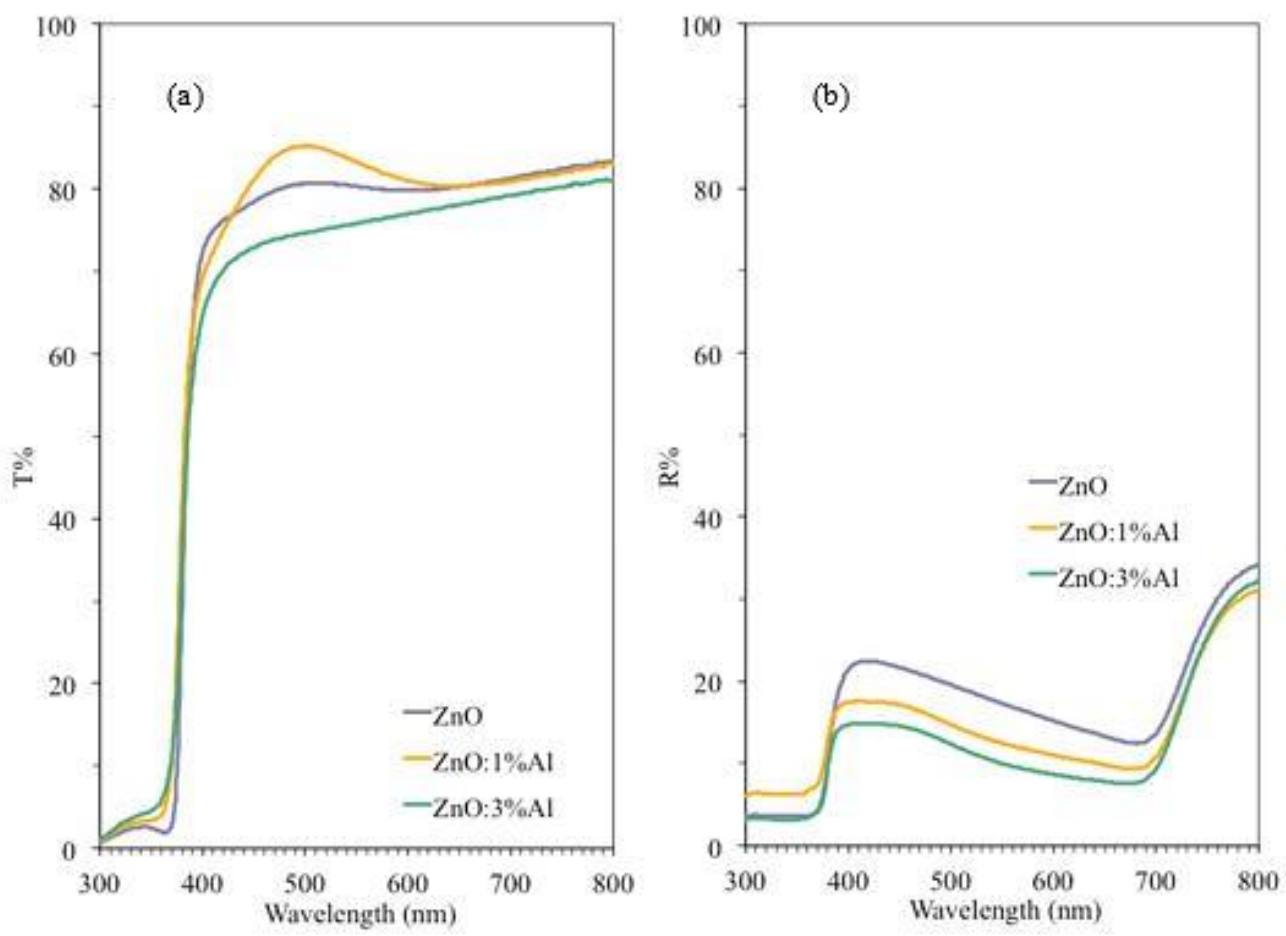

Figure 2. The transmittance (a) and reflectance (b) spectra of the undoped and $\mathrm{Al}$ doped $\mathrm{ZnO}$ films 
Ilıcan / Anadolu Univ. J. of Sci. and Technology-A - Appl. Sci. and Eng. 17 (1) - 2016

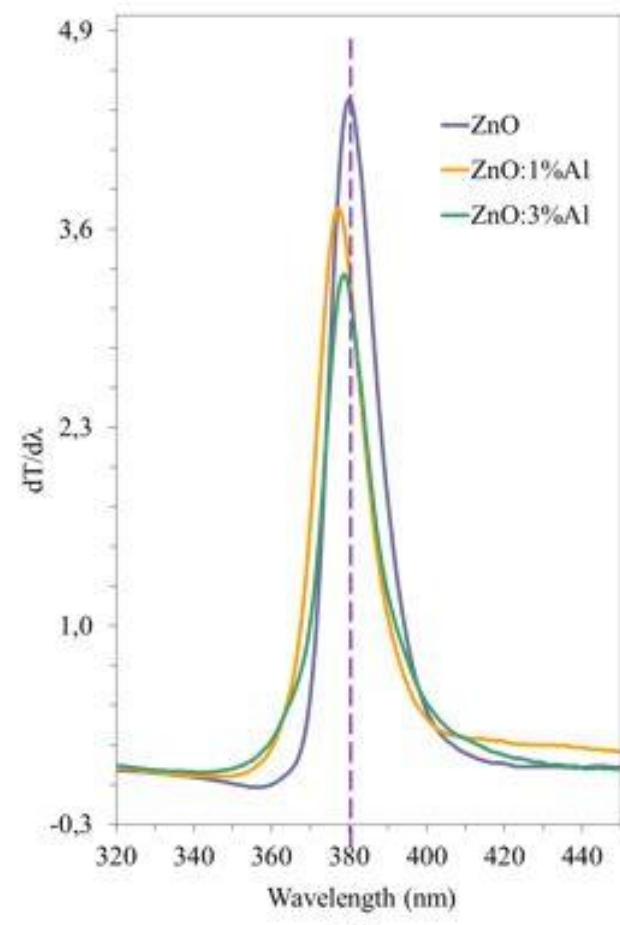

(a)

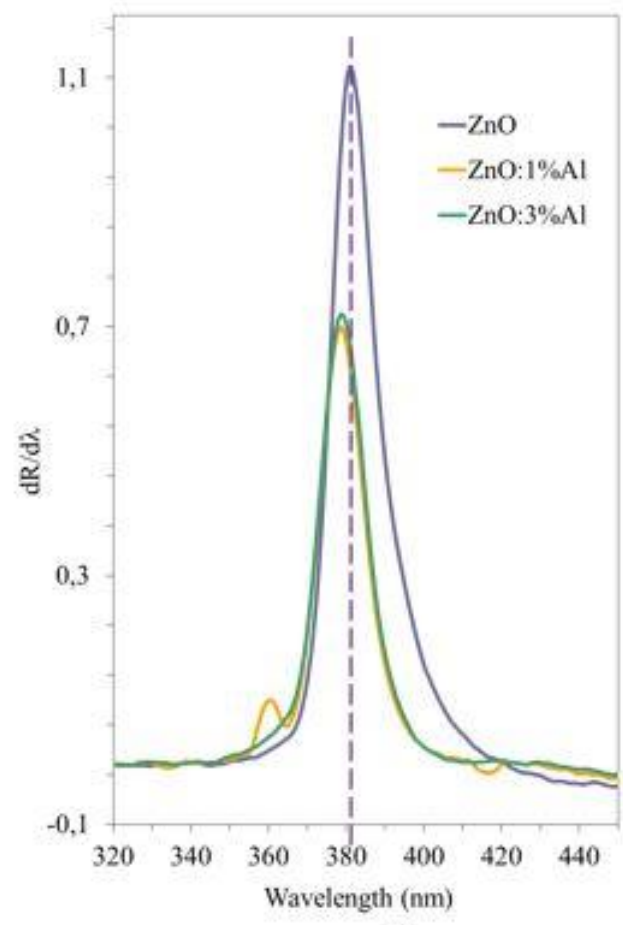

(b)

Figure 3. The plots of $\mathrm{d} T / \mathrm{d} \lambda$ (a) and $\mathrm{d} R / \mathrm{d} \lambda$ (b) versus wavelength for the undoped and $\mathrm{Al}$ doped $\mathrm{ZnO}$ films

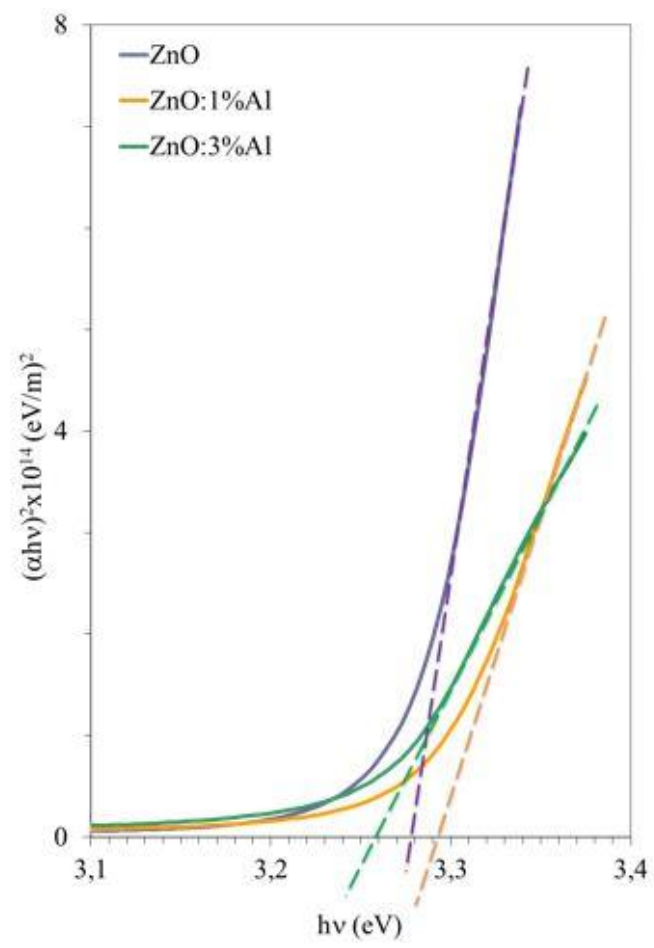

Figure 4. Tauc's plots of the undoped and $\mathrm{Al}$ doped $\mathrm{ZnO}$ films 


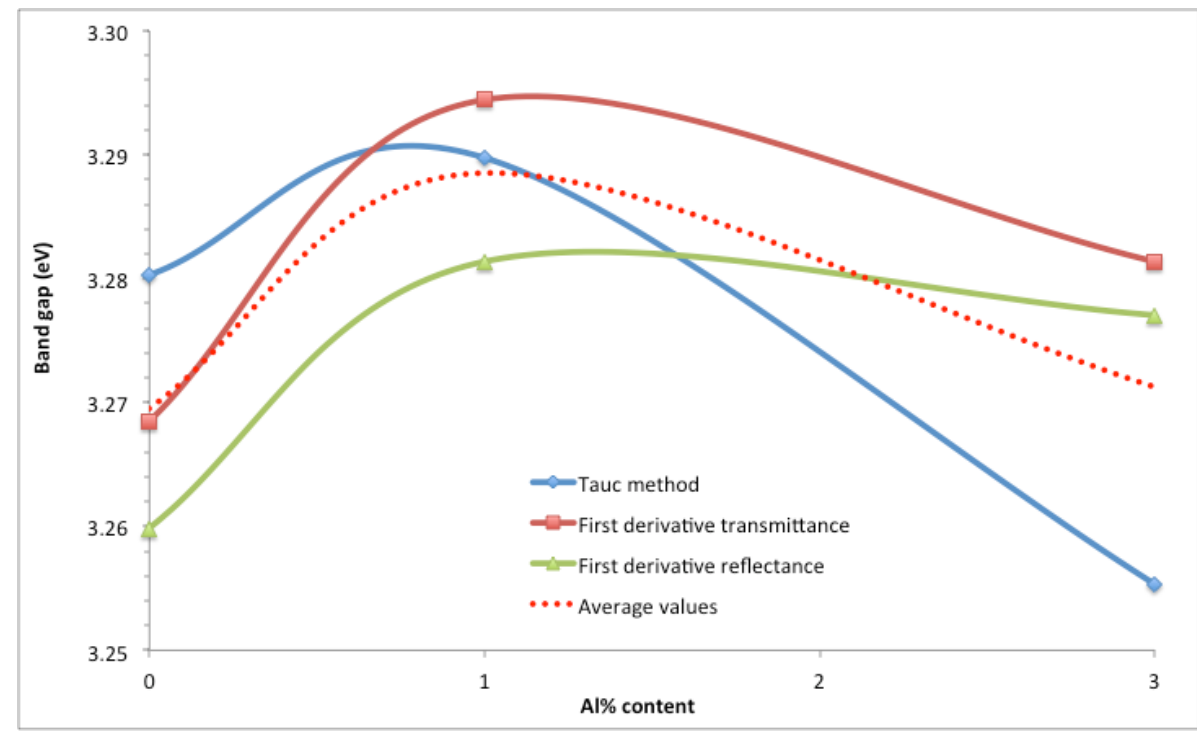

Figure 5. The absorption band edges of the undoped and $\mathrm{Al}$ doped $\mathrm{ZnO}$ films determined by different methods. The dashed lines indicate the average values for each film.

\subsection{Optical Constants of the Prepared Undoped and Al doped $\mathrm{ZnO}$ films}

The complex optical refractive index $\left(n^{\prime}\right)$ of the films plays a crucial role in designing and developing optical/optoelectronic devices. Therefore, it is extremely important to determine this optical constant. To investigate optical refractive index of the undoped and $\mathrm{Al}$ doped $\mathrm{ZnO}$ films, it was used following relation

$n^{\prime}=n(\lambda)+i k(\lambda)$

where $n$ is the refractive index (real part of $n^{\prime}$ ) and $k$ is the extinction coefficient (imaginary part of $n^{\prime}$ ). It is measured by reflectance spectra of the prepared films in order to calculate the $n$ of the films at different wavelengths, and it can be used the following equation [18]:

$n=\left(\frac{1+R}{1-R}\right)+\sqrt{\frac{4 R}{(1-R)^{2}}-k^{2}}$

The variation of calculated $n$ and $k$ values with wavelength are given in Fig. 6 . The average values of $n_{\text {ave }}$ and $k_{\text {ave }}$ in the visible region obtained for the undoped, 1 and $3 \% \mathrm{Al}$ doped $\mathrm{ZnO}$ films are presented in Table 1. Observing a decrease in refractive index may result from the variation in the film density.

The complex dielectric constant $\left(\varepsilon^{\prime}\right)$ is characterized by fundamental intrinsic property of the material and given by following relation:

$\varepsilon^{\prime}=\varepsilon_{1}+i \varepsilon_{2}$

where $\varepsilon_{1}$ and $\varepsilon_{2}$ are real and imaginary parts of the dielectric constant, respectively. They give information about the loss factor, and they are determined by using following relations [19]:

$\varepsilon_{1}=n^{2}-k^{2}$

and

$\varepsilon_{2}=2 n k$ 
Ilıcan / Anadolu Univ. J. of Sci. and Technology-A - Appl. Sci. and Eng. 17 (1) - 2016

Both of $\varepsilon_{1}$ and $\varepsilon_{2}$ values are determined Eqs. (6) and (7) in the UV-visible range. Fig.7 is presented the calculated $\varepsilon_{1}$ and $\varepsilon_{2}$ values as a function of wavelength.

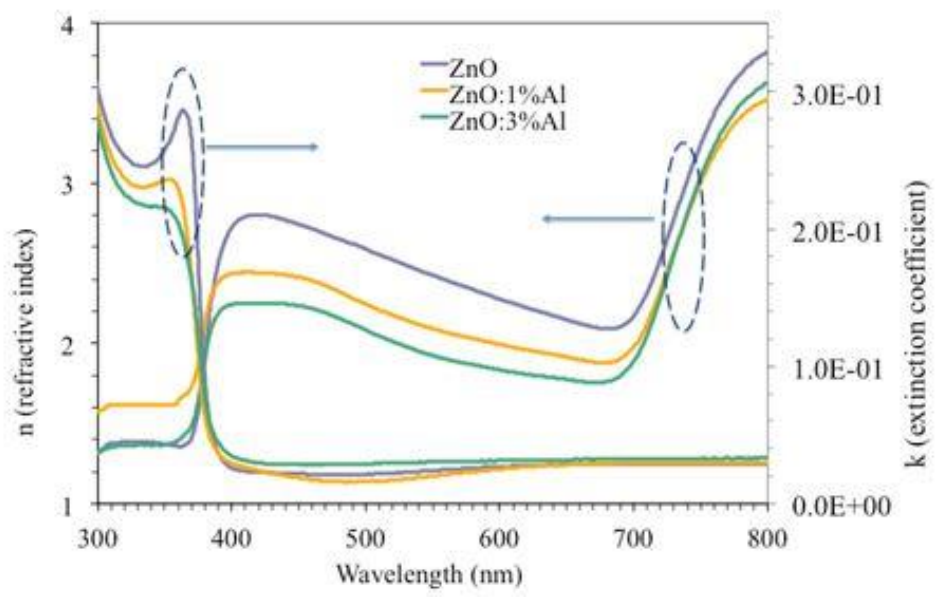

Figure 6. The variation of refractive index and extinction coefficient with wavelength for the undoped and $\mathrm{Al}$ doped $\mathrm{ZnO}$ films

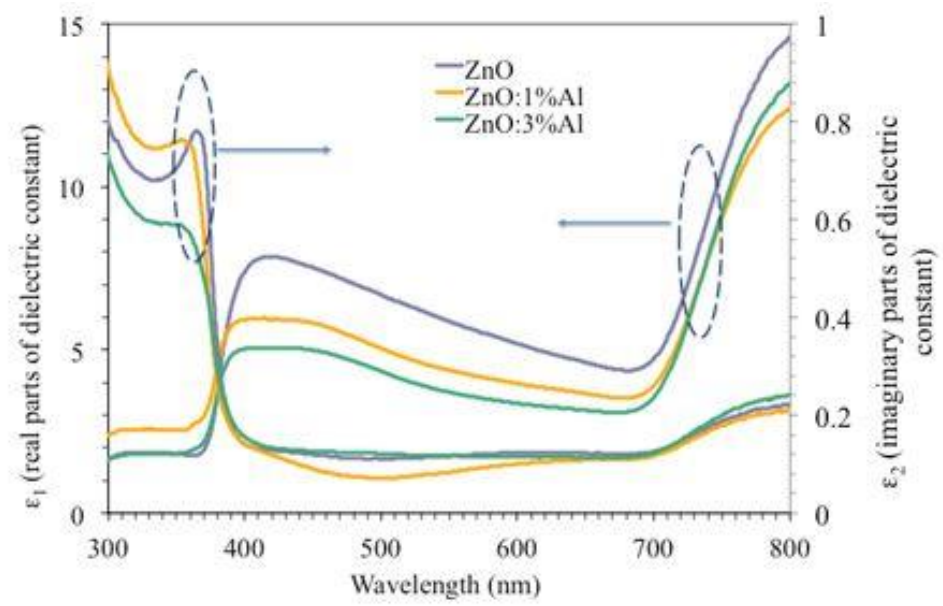

Figure 7. The variation of real and imaginary parts of dielectric constants with wavelength for the undoped and $\mathrm{Al}$ doped $\mathrm{ZnO}$ films

Table 1. The optical parameters of undoped and $\mathrm{Al}$ doped $\mathrm{ZnO}$ films

\begin{tabular}{ccccccc}
\hline Film & $\boldsymbol{T}_{\text {ave }} \boldsymbol{\%}$ & $\boldsymbol{R}_{\text {ave }} \boldsymbol{\%}$ & $\boldsymbol{n}_{\text {ave }}$ & $\boldsymbol{k}_{\text {ave }} \boldsymbol{x} \mathbf{1 0}^{-2}$ & $\boldsymbol{E}_{\text {lave }}$ & $\boldsymbol{\varepsilon}_{\text {2ave }} \boldsymbol{X} \mathbf{1 0}^{-2}$ \\
\hline $\mathrm{ZnO}$ & 80.3 & 19.6 & 2.61 & 2.58 & 7.03 & 1.35 \\
$\mathrm{ZnO}: 1 \% \mathrm{Al}$ & 81.4 & 15.7 & 2.33 & 2.45 & 5.62 & 1.15 \\
$\mathrm{ZnO}: 3 \% \mathrm{Al}$ & 76.5 & 14.0 & 2.22 & 3.11 & 5.17 & 1.38 \\
\hline
\end{tabular}




\subsection{Dispersion Parameters of the 3\% Al Doped ZnO Film}

The dispersion parameters of the films are also important due to play a significant role in designing of the optical devices. The dispersive refractive index data (in range of $h v<E_{g}$ ) were analyzed with using the single oscillator model proposed by Wemple and DiDomenico. This model is related to the dielectric response for transitions under the optical band gap. The experimental data of the undoped and/or doped $\mathrm{ZnO}$ were successfully applied to this model by the researchers, and reported [6, 20-24]. Therefore, to analyze the refractive index dispersion of the prepared films, the single oscillator model was used in this study. It is given by [25]

$n^{2}-1=\frac{E_{o} E_{d}}{E_{o}^{2}-E^{2}}$

where $E_{o}$ is the single oscillator energy and $E_{d}$ is the dispersion energy, which is a measure of the intensity of the inter band optical transitions. $\left(n^{2}-1\right)^{-1}$ vs. $(h v)^{2}$ plots for the prepared films was plotted. The $\left(n^{2}-1\right)^{-1}$ vs. $(h v)^{2}$ plot of $3 \% \mathrm{Al}$ doped $\mathrm{ZnO}$ film obeys the single-oscillator model. $E_{o}$ and $E_{d}$ values were determined from the slope and intercept on the vertical axis, and found to be 5.181 and $14.846 \mathrm{eV}$, respectively. The $E_{o}$ value can be considered as an average energy gap and was found to be in proportion to the $E_{g}$ value $\left(E_{g}<E_{o}<2 E_{g}\right.$ ). The determined dispersion parameters in this study are good agreement with earlier reported values $[26,27]$.

A measure of interband transition strengths can be provided from the $M_{-1}$ and $M_{-3}$ moments of the optical dispersion spectra. A relation between the dispersion parameters and the moments can be expressed as [25]

$E_{o}^{2}=\frac{M_{-1}}{M_{-3}}$

and

$E_{d}^{2}=\frac{M_{-1}^{3}}{M_{-3}}$

The $M_{-1}$ and $M_{-3}$ values of the $3 \% \mathrm{Al}$ doped $\mathrm{ZnO}$ film was determined, and found to be 2.865 and $0.107 \mathrm{eV}^{-2}$, respectively.

\section{CONCLUSIONS}

$\mathrm{ZnO}$ films with different $\mathrm{Al}$ content were prepared by sol gel method using spin coating technique and the crystallinity and optical parameters of these films were studied by XRD and UV-vis spectrophotometer, respectively. The XRD spectra indicate that the undoped and $\mathrm{Al}$ doped $\mathrm{ZnO}$ films are highly textured and zincite phase. On the other hand, they have (002) preferred orientation and the crystalline quality of the films enhanced with increasing Al content. The optical transmittance was found to above $76 \%$. The values of the $E_{g}$ values of the prepared films were determined from the plot of first derivative transmittance and diffuse reflectance vs. wavelength and Tauc method. The optical constants such as refractive index, extinction coefficient and dielectric constants were calculated for the prepared films. The single oscillator model was used to analyze the refractive index dispersion of the prepared films. The obtained dispersion parameters suggest that the single-oscillator model is valid for $3 \% \mathrm{Al}$ doped film.

In conclusion, in this study, undoped and $\mathrm{Al}$ doped $\mathrm{ZnO}$ films were successfully prepared by the low cost spin coating technique onto glass substrates. Moreover, it was observed that aluminum incorporation played an important role on the crystal quality and all the optical parameters of $\mathrm{ZnO}$. 


\section{ACKNOWLEDGEMENT}

This work was supported by Anadolu University Commission of Scientific Research Projects under Grant No. 1305F082.

\section{REFERENCES}

[1] Özgür Ü, Morkoç H. Optical Properties of $\mathrm{ZnO}$ and Related Alloys. In: Jagadish C, Pearton SJ, editors. Zinc Oxide Bulk, Thin Films and Nanostructures, Hong Kong: Elsevier, 2006, pp.175.

[2] Al-Ghamdi AA, Al-Hartomy OA, El Okr M, Nawar AM, El-Gazzar S, El-Tantawy F, Yakuphanoglu F. Semiconducting properties of Al doped ZnO thin films. Spectrochim Acta A 2014; 131: 512-517.

[3] Benhaliliba M, Benouis CE, Aida MS, Yakuphanoglu F, Juarez AS. Indium and aluminium-doped ZnO thin films deposited onto FTO substrates: nanostructure, optical, photoluminescence and electrical properties. J Sol Gel Sci Tech 2010; 55: 335-342.

[4] Benhaliliba M, Benouis CE, Mouffak Z, Ocak YS, Tiburcio-Silver A, Aida MS, Garcia AA, Tavira A, Juarez AS. Preparation and characterization of nanostructures of In-doped $\mathrm{ZnO}$ films deposited by chemically spray pyrolysis: Effect of substrate temperatures. Superlattice Microst 2013; 63: 228-239.

[5] Caglar Y, Caglar M, Ilican S. Microstructural, optical and electrical studies on sol gel derived ZnO and ZnO:Al films. Curr Appl Phys 2012; 12: 963-968.

[6] Phan DT, Farag AA. M, Yakuphanoglu F, Chung GS. Optical and photoluminescence properties of Ga doped ZnO nanostructures by sol-gel method. J Electroceramics 2012; 29: 12-22.

[7] Takci DK, Tuzemen ES, Kara K, Yilmaz S, Esen R, Baglayan O. Influence of Al concentration on structural and optical properties of Al-doped ZnO thin films. J Mater Sci.-Mater Elect 2014; 25: 20782085.

[8] Yilmaz M. Investigation of characteristics of $\mathrm{ZnO}$ :Ga nanocrystalline thin films with varying dopant content. Mater Sci Semicon Process 2015; 40: 99-106.

[9] Kim YS, Tai WP. Electrical and optical properties of Al-doped $\mathrm{ZnO}$ thin films by sol-gel process. Appl Sur Sci 2007; 253: 4911-4916.

[10] Khan MAM, Kumar S, Khan MN, Ahamed M, Al Dwayyan AS. Microstructure and blueshift in optical band gap of nanocrystalline $\mathrm{Al}_{\mathrm{x}} \mathrm{Zn}_{1-\mathrm{x}} \mathrm{O}$ thin films. J Luminescence 2014; 155: 275-281.

[11] Kim N S, Yim KG, Son JS, Leem JY. Effects of Al Concentration on Structural and Optical Properties of Al-doped ZnO Thin Films. Bull Korean Chem Soc 2012; 33: 1235-1241.

[12] Cho GS, Kim MS, Yim KG, Lee J, Leem JY. Effects of Aluminum Chloride Concentrations on Structural and Optical Properties of Al-doped ZnO Thin Films Prepared by the Sol-Gel Method. Korean J Met Mater 2012; 50: 847-854.

[13] Xue SW, Zu XT, Zheng WG, Deng HX, Xiang X. Effects of Al doping concentration on optical parameters of ZnO: Al thin films by sol-gel technique. Physica B 2006; 381: 209-213.

[14] Mondal S, Kanta K P, Mitra P. Preparation of Al-doped ZnO (AZO) Thin Film by SILAR. J Phys Sci 2008; 12: 221-229.

[15] Baba K, Lazzaroni C, Nikravech M. ZnO and Al doped ZnO thin films deposited by Spray Plasma: 
Ilican / Anadolu Univ. J. of Sci. and Technology-A - Appl. Sci. and Eng. 17 (1) - 2016

Effect of the growth time and Al doping on microstructural, optical and electrical properties. Thin Solid Films 2015; 595: 129-135.

[16] Tauc J. Amorphous and Liquid Semiconductors. New York, USA: Plenum Press, 1974.

[17] Gürbüz O, Güner S. Role of annealing temperature on electrical and optical properties of Al-doped ZnO thin films. Ceram Int 2015; 41: 3968-3974.

[18] Abeles F. (Ed.) Optical Properties of Solids. Amsterdam: North-Holland Publishing Company, 1972.

[19] Hodgson JN. Optical absorption and dispersion in Solids. London, UK: Chapman and Hall LTD, 1970.

[20] Aksoy S, Caglar Y, Ilican S, Caglar M. Sol-gel derived Li-Mg co-doped ZnO films: Preparation and characterization via XRD, XPS, FESEM. J Alloy Compd 2012; 512: 171-178.

[21] Caglar M, Yakuphanoglu F. Structural and optical properties of copper doped ZnO films derived by sol-gel. Appl Sur Sci 2012; 258: 3039-3044.

[22] Caglar M, Caglar Y, Ilican S. Investigation of the effect of Mg doping for improvements of optical and electrical properties. Physica B 2016; 485: 6-13.

[23] Ilican S. Effect of Na doping on the microstructures and optical properties of $\mathrm{ZnO}$ nanorods. J Alloy Compd 2013; 553: 225-232.

[24] Ocakoglu K, Mansour ShA, Yildirimcan S, Al-Ghamdi AA, El-Tantawy F, Yakuphanoglu F. Microwave-assisted hydrothermal synthesis and characterization of $\mathrm{ZnO}$ nanorods. Spectrochim Acta A 2015; 148: 362-368.

[25] Wemple SH, Didomenico M. Behavior of the Electronic Dielectric Constant in Covalent and Ionic Materials. Phys Rev B 1971; 3: 1338-1351.

[26] Gao XY, Liang Y, Lin QG. Analysis of the Optical Constants of Aluminum-doped Zinc-oxide Films by using the Single-oscillator Model. J Korean Phys Soc 2010; 57: 710-714.

[27] Oriaku CI, Osuwa JC. On the Optical Dispersion Parameters of Thin Film $\mathrm{Al}^{3+}$ Doped $\mathrm{ZnO}$ Transparent Conducting Glasses. J Ovonic Res 2009; 5: 23-218. 